\title{
Dyella yeojuensis sp. nov., isolated from greenhouse soil in Korea
}

Correspondence

Soon-Wo Kwon

swkwon@rda.go.kr

\section{Byung-Yong Kim, ${ }^{1}$ Hang-Yeon Weon, ${ }^{2}$ Kang-Hyo Lee, ${ }^{2}$ Soon-Ja Seok, ${ }^{2}$ Soon-Wo Kwon, ${ }^{1}$ Seung-Joo Go ${ }^{1}$ and Erko Stackebrandt ${ }^{3}$}
1,2Korean Agricultural Culture Collection (KACC), Genetic Resources Division, National Institute of Agricultural Biotechnology ${ }^{1}$, and Applied Microbiology Division, National Institute of Agricultural Science and Technology², Rural Development Administration (RDA), Suwon 441-707, Republic of Korea
${ }^{3}$ Deutsche Sammlung von Mikroorganismen und Zellkulturen $\mathrm{GmbH}$, Mascheroder Weg $1 \mathrm{~b}$, D-38124 Braunschweig, Germany

\begin{abstract}
A novel strain, R2A16-10 ${ }^{\top}$, was isolated from greenhouse soil in Yeoju, Korea. The taxonomy of strain R2A16-10 ${ }^{\top}$ was studied by using polyphasic methods. On the basis of 16S rRNA gene sequence analyses, strain R2A16-10 $0^{\top}$ was found to be phylogenetically related to type strains of Dyella species (96.7-96.9\%), Frateuria aurantia DSM 6220 ${ }^{\top}$ (96.5\%), Fulvimonas soli LMG $19981^{\top}(96 \cdot 3 \%)$ and Rhodanobacter species (94.9-95.7\%). Strain R2A16-10 ${ }^{\top}$, which produced yellow-coloured colonies, was Gram-negative, rod-shaped (0.3-0.4 $\times 1.5-3.5 \mu \mathrm{m})$ and motile. The predominant fatty acids were $17: 1$ iso $\omega 9 c(25 \cdot 5 \%), 15: 0$ iso $(18 \cdot 7 \%)$ and $17: 0$ iso $(14.6 \%)$, and the major hydroxy fatty acids were $11: 0$ iso $3-\mathrm{OH}(5 \cdot 0 \%), 13: 0$ iso $3-\mathrm{OH}$ $(3.4 \%)$ and $17: 0$ iso $3-\mathrm{OH}(1.0 \%)$. The major isoprenoid quinone was $\mathrm{Q}-8$. The $\mathrm{G}+\mathrm{C}$ content of the DNA of the type strain was $63.0 \mathrm{~mol} \%$. On the basis of the data from this study, strain R2A16-10 ${ }^{\top}$ represents a novel species of the genus Dyella, for which the name Dyella yeojuensis sp. nov. is proposed. The type strain is R2A16-10 ${ }^{\top}\left(=\operatorname{KACC} 11405^{\top}=\mathrm{DSM} 17673^{\top}\right)$.
\end{abstract}

Greenhouse soil is characterized by high ionic strength and high concentrations of organic compounds in comparison with upland soil. We isolated bacterial isolates from greenhouse soil cultivated with lettuce (Lactuca sativa L.) in the Yeoju region of Korea. Of these, one yellow-coloured bacterial isolate, R2A16-10 ${ }^{\mathrm{T}}$, was shown to be closely related to Dyella species and Frateuria aurantia on the basis of 16S rRNA gene sequences. The genus Dyella was described recently by Xie \& Yokota (2005). At present, the genus Dyella includes two species, Dyella japonica and Dyella koreensis (An et al., 2005). This genus is closely related to the genera Fulvimonas, Frateuria and Rhodanobacter on the basis of $16 \mathrm{~S}$ rRNA gene sequence analysis. D. japonica can be differentiated from Frateuria aurantia on the basis of fatty acid profiles and some phenotypic features such as growth at $\mathrm{pH} 4 \cdot 5$, acid production from carbohydrates and enzyme reactions.

Strain R2A16-10 ${ }^{\mathrm{T}}$ was cultivated on R2A medium (Difco) at $\mathrm{pH} 7 \cdot 0$ and $28^{\circ} \mathrm{C}$, and maintained on R2A medium.

The GenBank/EMBL/DDBJ accession number for the 16S rRNA gene sequence of strain R2A16-10' is DQ181549.

Differentiating properties among strain R2A $16-10^{\top}$, members of the genus Dyella and Frateuria aurantia are shown in Supplementary Table S1 available in IJSEM Online.
Frateuria aurantia DSM $6220^{\mathrm{T}}$, D. japonica DSM $16301^{\mathrm{T}}$ and D. koreensis $\mathrm{BB} 4^{\mathrm{T}}$ were used as reference strains. Standard physiological and biochemical tests were performed at $28^{\circ} \mathrm{C}$. Gram staining was performed by using a Difco Gramstain kit. Catalase activity was tested with a $3 \%(\mathrm{v} / \mathrm{v}) \mathrm{H}_{2} \mathrm{O}_{2}$ solution. Oxidase activity, degradation of agar $(1 \cdot 5 \%, \mathrm{w} / \mathrm{v})$, hydrolysis of aesculin, starch, casein, gelatin and DNA and indole production were tested according to the methods of Smibert \& Krieg (1994). Hydrolysis of tyrosine $(0.5 \%$, w/v) was tested on R2A agar medium. Hydrolysis of carboxymethylcellulose and Whatman powder CF11 was tested by overlaying R2A agar with a thin layer of $0 \cdot 1 \%$ each component in tap-water agar. The urease test was performed using the method described by MacFaddin (2000). Growth on AE broth $[1.5 \%(\mathrm{w} / \mathrm{v})$ glucose, $0.2 \%(\mathrm{w} / \mathrm{v})$ yeast extract, $0 \cdot 3 \%(\mathrm{w} / \mathrm{v})$ peptone, $6.5 \%(\mathrm{v} / \mathrm{v})$ acetic acid and $2 \%(\mathrm{v} / \mathrm{v})$ ethanol] (Entani et al., 1985) was checked at $28^{\circ} \mathrm{C}$ on a rotary shaker for 30 days. The $\mathrm{pH}$ range for growth was determined in R2A broth adjusted with citrate-phosphate buffer or Tris/HCl buffer (Breznak \& Costilow, 1994) to $\mathrm{pH} 4 \cdot 0-10 \cdot 0$, using increments of $0.5 \mathrm{pH}$ units. Growth at $1,2,3,5$ and $7 \% \mathrm{NaCl}(\mathrm{w} / \mathrm{v})$ was investigated in $\mathrm{R} 2 \mathrm{~A}$ broth. Growth at various temperatures $\left(5-50^{\circ} \mathrm{C}\right)$ was measured on R2A medium. Physiological and biochemical properties were further determined with API ZYM, API 20NE and API $50 \mathrm{CH}$ kits (bioMérieux). Tests involving 
commercial systems were generally performed according to the manufacturer's instructions. The API ZYM test strip was read after $4 \mathrm{~h}$ incubation at $30^{\circ} \mathrm{C}$, and API test strips were examined after $48 \mathrm{~h}$ at $28^{\circ} \mathrm{C}$. In the case of the API $50 \mathrm{CH}$ test strips, Frateuria aurantia DSM $6220^{\mathrm{T}}$ produced reaction results after $48 \mathrm{~h}$ at $28^{\circ} \mathrm{C}$, whereas the reactions of type strains of the genus Dyella were delayed, being observed after 7 days at $28^{\circ} \mathrm{C}$.

Cells grown on R2A agar plates for $48 \mathrm{~h}$ were used for the analysis of the cellular fatty acid composition. Fatty acid methyl esters were extracted and prepared by using the standard protocol of the Microbial Identification System (MIDI; Microbial ID). Isoprenoid quinones were analysed by HPLC as described previously (Groth et al., 1996). The G + C content (mol\%) was determined by HPLC analysis of deoxyribonucleosides as described by Mesbah et al. (1989), using a reverse-phased column (Supelcosil LC-18-S; Supelco).

The 16S rRNA gene sequence was determined by PCR amplification (Kwon et al., 2003) and direct sequencing (Hiraishi, 1992). A phylogenetic analysis was carried out using 16S rRNA gene sequences of 1498 nucleotide bases, from positions 37 to 1510 (Escherichia coli numbering system). The neighbour-joining and maximum-parsimony methods were carried out using MEGA, version 2.1 (Kumar et al., 2001), and the maximum-likelihood method (DNAML) was carried out using PHYLIP, version 3.5 (Felsenstein, 1993). The resulting trees and topology were evaluated by bootstrap analysis (Felsenstein, 1985) based on 1000 resamplings.

After 2 days growth on R2A, the colonies of strain R2A16$10^{\mathrm{T}}$ were circular, yellow in colour and convex with clear margins. The strain grew well on R2A, tryptic soy agar

Table 1. Comparison of selected characteristics among strain R2A $16-10^{\top}$ and members of the genera Dyella and Frateuria

Strains: 1, strain R2A16-10 ${ }^{\mathrm{T}}$; 2, D. japonica DSM $16301^{\mathrm{T}} ; 3, D$. koreensis $\mathrm{BB}^{\mathrm{T}}$; 4, Frateuria aurantia DSM $6220^{\mathrm{T}}$. Data are from An et al. (2005), Bernardet et al. (1996), Im et al. (2004), Nalin et al. (1999), Swings et al. (1984), Xie \& Yokota (2005) and this study. All of the strains were negative for starch hydrolysis. Symbols: +, positive; -, negative; $\mathrm{W}$, weak; ND, not determined.

\begin{tabular}{|lcccc|}
\hline Characteristic & $\mathbf{1}$ & $\mathbf{2}$ & $\mathbf{3}$ & $\mathbf{4}$ \\
\hline DNA G+C content (mol\%) & $63 \cdot 0$ & $63 \cdot 4-64 \cdot 0$ & $63 \cdot 8$ & $63 \cdot 5$ \\
Motility & + & + & - & + \\
Oxidase/catalase & $+/+$ & $-/+$ & $+/ \mathrm{w}$ & $-/+$ \\
Hydrolysis of: & & & & \\
$\quad$ Cellulose & - & - & + & - \\
$\quad$ Casein & + & - & + & - \\
Growth at pH $4 \cdot 5$ & - & - & $\mathrm{ND}$ & + \\
Growth at $4 \% \mathrm{NaCl}$ & + & - & $\mathrm{w}$ & - \\
Growth on $\mathrm{AE}$ medium & - & - & $\mathrm{ND}$ & + \\
\hline
\end{tabular}

(Difco) and nutrient agar (Difco) but grew weakly on MacConkey agar (Difco). Strain R2A16-10 ${ }^{\mathrm{T}}$ was a Gramnegative rod, $0 \cdot 3-0.4 \times 1 \cdot 5-3.5 \mu \mathrm{m}$ in size. In API $20 \mathrm{NE}$ tests, the micro-organism assimilated D-glucose, D-mannose, $\mathrm{N}$-acetylglucosamine and D-maltose and showed positive reactions for aesculin and gelatin hydrolysis and $\beta$-galactosidase activity. In API $50 \mathrm{CH}$ tests, there were positive reactions only for D-galactose, D-glucose, D-fructose, Dmannose and aesculin. In APIZYM tests, the micro-organism showed positive reactions for alkaline phosphatase, esterase (C4), esterase lipase (C8), leucine arylamidase, valine arylamidase, cystine arylamidase, acid phosphatase, naphtholAS-BI-phosphohydrolase, $\alpha$-galactosidase, $\beta$-galactosidase, $\alpha$-glucosidase, $\beta$-glucosidase and $N$-acetyl- $\beta$-glucosaminidase activities (see Supplementary Table S1 available in IJSEM Online). Differentiating properties among strain R2A16-10 ${ }^{\mathrm{T}}$, members of the genus Dyella and Frateuria aurantia are shown in Table 1 and Supplementary Table S1.

Strain R2A16- $10^{\mathrm{T}}$ contained Q-8 as the major isoprenoid quinone. It had a fatty acid profile very similar to those of other Dyella species, having a predominance of branched fatty acids, with $17: 1$ iso $\omega 9 c(21 \cdot 5 \%), 16: 0$ iso $(21 \cdot 3 \%)$,

Table 2. Cellular fatty acid composition of strain R2A16$10^{\top}$ in comparison with those of related species

Strains: 1, strain R2A16-10 $0^{\mathrm{T}} ; 2$, D. japonica DSM $16301^{\mathrm{T}} ; 3, \mathrm{D}$. koreensis $\mathrm{BB} 4^{\mathrm{T}}$; 4, Frateuria aurantia DSM $6220^{\mathrm{T}}$. Values are percentages of total fatty acids. -, Not detected or $<1 \%$. ECL, Equivalent chain length.

\begin{tabular}{|lcccc|}
\hline Fatty acid & $\mathbf{1}$ & $\mathbf{2}$ & $\mathbf{3}$ & $\mathbf{4}$ \\
\hline $11: 0$ iso & $3 \cdot 7$ & $5 \cdot 0$ & $4 \cdot 5$ & - \\
Unknown (ECL 11·799) & $2 \cdot 3$ & $3 \cdot 1$ & $2 \cdot 5$ & - \\
$11: 0$ iso 3-OH & $4 \cdot 2$ & $6 \cdot 0$ & $5 \cdot 5$ & - \\
$12: 0$ 2-OH & - & - & - & $2 \cdot 2$ \\
$12: 0$ 3-OH & - & - & - & $5 \cdot 7$ \\
$12: 0$ iso 3-OH & $1 \cdot 0$ & $1 \cdot 4$ & $1 \cdot 4$ & - \\
$14: 1 \omega 5 c$ & - & - & - & $1 \cdot 0$ \\
$14: 0$ iso & $1 \cdot 1$ & - & $1 \cdot 1$ & - \\
$14: 0$ & - & - & - & $3 \cdot 1$ \\
$13: 0$ iso 3-OH & $2 \cdot 4$ & $4 \cdot 0$ & $2 \cdot 3$ & $1 \cdot 2$ \\
$15: 0$ iso & $14 \cdot 5$ & $14 \cdot 6$ & $11 \cdot 1$ & $41 \cdot 2$ \\
$15: 0$ anteiso & $6 \cdot 9$ & $5 \cdot 1$ & $3 \cdot 6$ & $2 \cdot 4$ \\
$16: 0$ iso & $21 \cdot 3$ & $17 \cdot 5$ & $19 \cdot 2$ & - \\
$16: 0$ & $1 \cdot 8$ & $1 \cdot 5$ & $2 \cdot 5$ & $7 \cdot 5$ \\
$17: 1$ iso $\omega 9 c$ & $21 \cdot 5$ & $20 \cdot 3$ & $19 \cdot 0$ & $1 \cdot 8$ \\
$17: 0$ iso & $7 \cdot 9$ & $8 \cdot 5$ & $6 \cdot 7$ & $5 \cdot 3$ \\
$17: 0$ anteiso & $1 \cdot 6$ & $1 \cdot 8$ & $2 \cdot 9$ & - \\
$17: 0$ cyclo & - & - & - & $9 \cdot 8$ \\
$18: 0$ iso & $1 \cdot 2$ & $1 \cdot 3$ & $2 \cdot 6$ & - \\
$18: 0$ & - & - & - & $1 \cdot 2$ \\
$17: 0$ iso 3-OH & - & $1 \cdot 5$ & - & - \\
Summed feature $3 *$ & $5 \cdot 2$ & $5 \cdot 0$ & $7 \cdot 9$ & $10 \cdot 5$ \\
& & & & \\
\hline
\end{tabular}

${ }^{\star}$ Summed feature 3 comprises $15: 0$ iso $2-\mathrm{OH}$ and/or $16: 1 \omega 7 c$. 


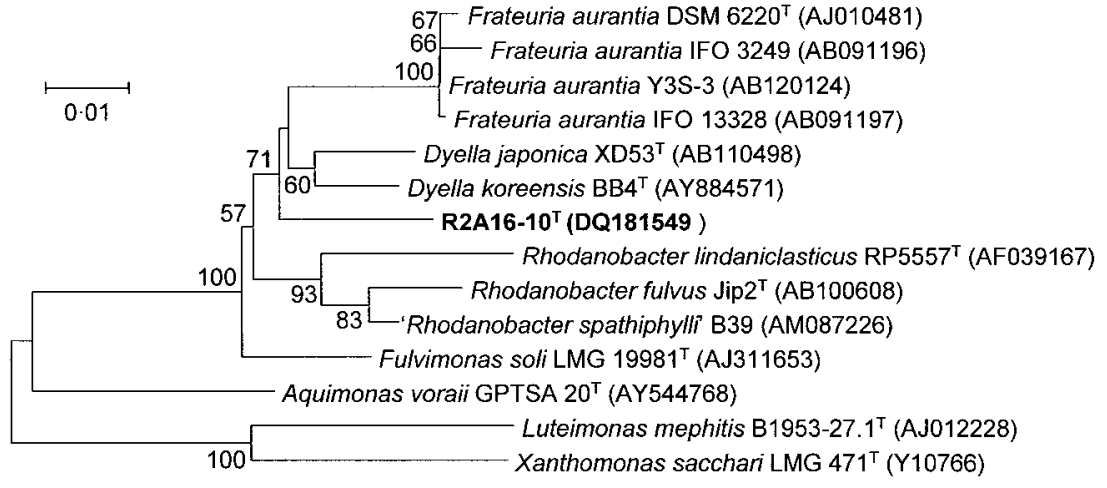

Fig. 1. Phylogenetic position of strain R2A16-10 $0^{\top}$ with respect to some members of the Gammaproteobacteria on the basis of $16 \mathrm{~S}$ rRNA gene sequences. Numbers at nodes indicate levels of bootstrap support (\%), based on a neighbour-joining analysis of 1000 resampled datasets. Bootstrap values below $50 \%$ are not shown. Bar, 1 nucleotide substitution per 100 nucleotides.
$15: 0$ iso $(14 \cdot 5 \%)$ and $17: 0$ iso $(7 \cdot 9 \%)$ as the major constituents. The major hydroxy fatty acids were $11: 0$ iso $3-\mathrm{OH}$ $(4 \cdot 2 \%), 13: 0$ iso $3-\mathrm{OH}(2 \cdot 4 \%)$ and $12: 0$ iso $3-\mathrm{OH}(1 \cdot 0 \%)$. The fatty acid profiles of Dyella species and isolate R2A16$10^{\mathrm{T}}$ could be clearly differentiated from that of Frateuria aurantia (Table 2). The DNA G $+\mathrm{C}$ content of strain $\mathrm{R} 2 \mathrm{~A} 16-10^{\mathrm{T}}$ was $63 \cdot 0 \mathrm{~mol} \%$.

Strain R2A16- $10^{\mathrm{T}}$ displayed high levels of $16 \mathrm{~S}$ rRNA gene sequence similarity with Dyella species $(96 \cdot 7-96 \cdot 9 \%)$ and Frateuria aurantia DSM $6220^{\mathrm{T}}(96 \cdot 5 \%)$. It formed a subline, which included Dyella species and Frateuria aurantia, supported by a bootstrap value of $71 \%$ (Fig. 1). Within the cluster, strains of Frateuria aurantia formed another compact cluster distinct from that for members of the genus Dyella. On the basis of the data from polyphasic studies including analyses of biochemical properties, fatty acid composition and the $16 \mathrm{~S}$ rRNA gene sequence, strain R2A16-10 ${ }^{\mathrm{T}}$ represents a novel species within the genus Dyella, for which the name Dyella yeojuensis sp. nov. is proposed.

\section{Description of Dyella yeojuensis sp. nov.}

Dyella yeojuensis (yeo.ju.en'sis. N.L. fem. adj. yeojuensis pertaining to Yeoju, a city in Korea, from where the type strain originated).

Cells are Gram-negative, aerobic, motile, catalase-positive and oxidase-positive. Colonies on R2A medium are yellow. Colonies after 2 days growth on R2A medium are circular, yellow in colour and convex with clear margins. Optimal growth occurs at $28^{\circ} \mathrm{C}$. Growth occurs at temperatures in the range $5-37^{\circ} \mathrm{C}$, at $\mathrm{pH}$ values in the range $4 \cdot 5-8 \cdot 5$ and at $0-5 \%(\mathrm{w} / \mathrm{v}) \mathrm{NaCl}$. Does not grow on AE medium. Hydrolyses aesculin, casein, DNA, gelatin and tyrosine. Does not hydrolyse starch, urea, CM-cellulose or Whatman powder CF11. The major isoprenoid quinone is Q-8. The predominant fatty acids are $17: 1$ iso $\omega 9 c, 16: 0$ iso, $15: 0$ iso and $17: 0$ iso. The major hydroxy fatty acids are $11: 0$ iso 3 $\mathrm{OH}, 13: 0$ iso $3-\mathrm{OH}$ and $12: 0$ iso $3-\mathrm{OH}$. The DNA G $+\mathrm{C}$ content of the type strain is $63.0 \mathrm{~mol} \%$.

The type strain, R2A16-10 $0^{\mathrm{T}} \quad\left(=\mathrm{KACC} \quad 11405^{\mathrm{T}}=\mathrm{DSM}\right.$ $\left.17673^{\mathrm{T}}\right)$, was isolated from greenhouse soil in Yeoju, Korea.

\section{References}

An, D.-S., Im, W.-T., Yang, H.-C., Yang, D.-C. \& Lee, S.-T. (2005). Dyella koreensis sp. nov., a $\beta$-glucosidase-producing bacterium. Int J Syst Evol Microbiol 55, 1625-1628.

Bernardet, J.-F., Segers, P., Vancanneyt, M., Berthe, F., Kersters, K. \& Vandamme, P. (1996). Cutting a Gordian knot: emended classification and description of the genus Flavobacterium, emended description of the family Flavobacteriaceae, and proposal of Flavobacterium hydatis nom. nov. (basonym, Cytophaga aquatilis Strohl and Tait 1978). Int J Syst Bacteriol 46, 128-148.

Breznak, J. A. \& Costilow, R. N. (1994). Physicochemical factors in growth. In Methods for General and Molecular Bacteriology, pp. 137154. Edited by P. Gerhardt, R. G. E. Murray, W. A. Wood \& N. R. Krieg. Washington, DC: American Society for Microbiology.

Entani, E., Ohmori, S., Masai, H. \& Suzuki, K. (1985). Acetobacter polyoxogenes sp. nov., a new species of an acetic acid bacterium useful for producing vinegar with high acidity. J Gen Appl Microbiol 31, 475-490.

Felsenstein, J. (1985). Confidence limits on phylogenies: an approach using the bootstrap. Evolution 39, 783-791.

Felsenstein, J. (1993). PHYLIP (phylogeny inference package), version 3.5. Distributed by the author. Department of Genome Sciences, University of Washington, Seattle, USA.

Groth, I., Schumann, P., Weiss, N., Martin, K. \& Rainey, F. A. (1996). Agrococcus jenensis gen. nov., sp. nov., a new genus of actinomycetes with diaminobutyric acid in the cell wall. Int J Syst Bacteriol 46, 234-239.

Hiraishi, A. (1992). Direct automated sequencing of $16 \mathrm{~S}$ rDNA amplified by polymerase chain reaction from bacterial cultures without DNA purification. Lett Appl Microbiol 15, 210-213.

Im, W.-T., Lee, S.-T. \& Yokota, A. (2004). Rhodanobacter fulvus sp. nov., a $\beta$-galactosidase-producing gammaproteobacterium. J Gen Appl Microbiol 50, 143-147.

Kumar, S., Tamura, K., Jakobsen, I. B. \& Nei, M. (2001). MEGA2: molecular evolutionary genetics analysis software. Tempe, AZ: Arizona State University.

Kwon, S. W., Kim, J. S., Park, I. C., Yoon, S. H., Park, D. H., Lim, C. K. \& Go, S. J. (2003). Pseudomonas koreensis sp. nov., Pseudomonas umsongensis sp. nov. and Pseudomonas jinjuensis sp. nov., novel species from farm soils in Korea. Int J Syst Evol Microbiol 53, 21-27.

MacFaddin, J. F. (2000). Biochemical Tests for Identification of Medical Bacteria, 3rd edn, pp. 424-438. Baltimore: Lippincott Williams \& Wilkins.

Mesbah, M., Premachandran, U. \& Whitman, W. B. (1989). Precise measurement of the $\mathrm{G}+\mathrm{C}$ content of deoxyribonucleic acid by highperformance liquid chromatography. Int J Syst Bacteriol 39, 159-167. 
Nalin, R., Simonet, P., Vogel, T. M. \& Normand, P. (1999). Rhodanobacter lindaniclasticus gen. nov., sp. nov., a lindane-degrading bacterium. Int J Syst Bacteriol 49, 19-23.

Smibert, R. M. \& Krieg, N. R. (1994). Phenotypic characterization. In Methods for General and Molecular Bacteriology, pp. 607-654. Edited by P. Gerhardt, R. G. E. Murray, W. A. Wood \& N. R. Krieg. Washington, DC: American Society for Microbiology.
Swings, J., De Ley, J. \& Gillis, M. (1984). Genus III. Frateuria Swings, Kersters, De Vos, Gossele and De Ley, 1980, 547 ${ }^{\mathrm{VP}}$. In Bergey's Manual of Systematic Bacteriology, vol. 1, pp. 210-213. Edited by N. R. Krieg \& J. G. Holt. Baltimore: Williams \& Wilkins.

Xie, C.-H. \& Yokota, A. (2005). Dyella japonica gen. nov., sp. nov., a $\gamma$-proteobacterium isolated from soil. Int J Syst Evol Microbiol 55, 753-756. 